\title{
Linguistic Pragmatism and Cultural Naturalism: Noncognitive Experience, Culture, and the Human Eros
}

Thomas M. Alexander

\section{(2) OpenEdition \\ Journals}

Electronic version

URL: http://journals.openedition.org/ejpap/299

DOI: 10.4000/ejpap.299

ISSN: 2036-4091

Publisher

Associazione Pragma

\section{Electronic reference}

Thomas M. Alexander, « Linguistic Pragmatism and Cultural Naturalism: Noncognitive Experience, Culture, and the Human Eros », European Journal of Pragmatism and American Philosophy [Online], VI-2 | 2014, Online since 24 December 2014, connection on 20 April 2019. URL : http:// journals.openedition.org/ejpap/299; DOI : 10.4000/ejpap.299

\section{(c) $(1) \odot$}

Author retains copyright and grants the European Journal of Pragmatism and American Philosophy right of first publication with the work simultaneously licensed under a Creative Commons AttributionNonCommercial-NoDerivatives 4.0 International License. 


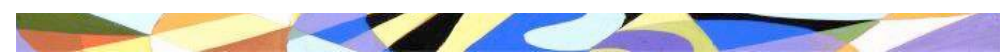

EUROPEAN JOURNAL OF PRAGMATISM AND AMERICAN PHILOSOPHY

COPYRIGHT (C 2009 ASSOCIAZIONE PRAGMA

Thomas M. Alexander*

Linguistic Pragmatism and Cultural Naturalism: Noncognitive Experience, Culture, and the Human Eros

\begin{abstract}
Contrary to some recent self-styled "linguistic pragmatists" who seek to dispense with the purportedly obsolete term "experience". this essay attempts to show that pragmatism cannot cogently dispense with experience, understanding that term in its Deweyan sense as "culture" and not some sort of mentalistic perception or state. Focusing on Robert Brandom's recent Perspectives on Pragmatism, I show how the very assumptions that Dewey meant to call into question with his "instrumentalist turn" in 1903 are enshrined in Brandom's "new and improved" form of pragmatism. Judged in terms of its pragmatic consequences, Brandom's linguistic pragmatism returns to the well trodden paths and problems of analytic philosophy and not the radical approach that Dewey's "cultural naturalism" (Dewey's name for his philosophy) offers. The fundamental issue is not, I contend, between types of pragmatism at all but between conceptions of human nature and what a human life is. John Stuart Mill once said of Bentham that, for an empiricist, he had really very little experience, especially of human nature. I am afraid that the same judgment here is passed on those wishing to dispense with experience and somehow retain pragmatism.
\end{abstract}

\title{
Introduction
}

John Stuart Mill remarks that although Bentham was an empiricist, his empiricism, at least in terms of knowledge of human nature, was that "of one who has had little experience". I am afraid that may well reflect the judgment of this essay regarding "linguistic pragmatism" insofar as it wishes to dispense with the idea of experience in opposition to the more classically grounded pragmatists, like myself, who affirm that experience is central and vitally indispensable to the very thought of pragmatism. Mill adds to his comment the observation that Bentham's simplistic, almost childlike, conception of human nature was combined with a remarkable gift for drawing inferences. The result was that, however sharp his reasoning, "his general conception of human nature and life furnished him with an unusually slender stock of premises". This, in Mill's eyes, was fatal: "The first question in regard to any man of speculation is What is his theory of human life?" 1 . I find his comment pertinent and I think this the theory of human life - really should be the topic of our debate.

Linguistic pragmatism, represented here by Robert Brandom's recent Perspectives on Pragmatism (PP hereafter), confines its vision of human existence to theories of linguistic meaning, where language is thought of as largely concerned with epistemological issues, such as representationalism $v s$. functionalism. This is done to update pragmatism and make it socially acceptable to analytically trained philosophers. In doing so it seems unaware of a larger and richer semiotic approach to meaning or a larger and richer view of experience beyond the circumscribed issue of knowledge. In fact, it really is a continuation of the narrow commitments of recent Anglophone philosophy rather than some new development within "pragmatism" per se. A label

* Southern Illinois Univeristy [talex@siu.edu]

1. Mill (1961: 23-25). 
has been appropriated, not a philosophy - one of the reasons it is a bad idea to approach philosophy in terms of its "isms"2. Aside from the narrow focus, linguistic pragmatism displays a poor understanding of the classical experiential pragmatism it believes to have surpassed: it is, at best, thinly informed, selective in its readings, and often inaccurate or just plain wrong in its claims about the classical pragmatists and the pragmatist tradition ${ }^{3}$. This criticism is perhaps more a matter of scholarship than philosophy (though one wonders about any self-professed empiricism that treats its data so arbitrarily). But it certainly weakens any claim that linguistic pragmatism is a genuine development of the pragmatist outlook rather than a misleading borrowing of a now-fashionable term. And that alone calls into doubt the cogency of the call to eliminate "experience" from the basic pragmatist vocabulary.

In this essay I will touch on certain key themes of the classical pragmatist idea of experience that I believe are fundamental to the very idea of "pragmatism" and which cannot be lost without changing the meaning of what pragmatism is. Insofar as John Dewey developed the most robust understanding of experience, I will use his thought to represent what "experiential pragmatism" embraces and "linguistic pragmatism" does not. This will call for some examination of Dewey's texts, but I do not believe that the exegesis will be misplaced, given, as I said, the rather limited way his thought has been understood, when it has been understood at all, by the linguistic pragmatists. In fact, upon inspection, linguistic pragmatism seems to endorse positions similar to those explicitly criticized by Dewey in the course of articulating both his instrumentalism and his general theory of experience. Thus I believe the debate between linguistic and experiential pragmatism reflects a fundamental philosophical conflict - a conflict about the purpose of philosophy and its conception of human existence - and not a petty "in-house" controversy between "new-fangled" and "oldfashioned" versions of pragmatism.

I will discuss four points about Dewey's concept of experience that are at odds with linguistic pragmatism. They are listed below with a brief synopsis:

The Irreducibility of the Noncognitive. The noncognitive dimension of experience is essential for pragmatic inquiry; "pragmatism" or instrumentalism as a theory of inquiry does not make sense without it. This limits the extent of cognition and prevents seeing the context or background in terms of incipiently articulated propositionally structured beliefs or desires. Rather, this broader field is better described as "aesthetic" than as one of even implicit cognitive content. Philosophy should aim at what Dewey (following Keats) calls "half-knowledge" instead of some pancognitivist program4.

2. "Pragmatism" itself is a poor term to refer to the philosophies of C. S. Peirce, William James, John Dewey, and George Herbert Mead. At best it captures only a portion of their positions but misses Peirce's metaphysics and semeiotic and James's radical empiricism. Dewey's preferred term for his philosophy as a whole (not just his instrumentalism) was "cultural naturalism".

3. Brandom, for example, tells us that: James is a Kantian working through Hegel (PP: 3-4); Peirce, James and Dewey are "materialists" (42); and Dewey's theory of truth is the satisfaction of subjective desire (51-52, 72-77). Brandom's reliance on Louis Menand's flawed, quirky The Metaphysical Club is another indication of the book's weak historical grounding (43-45).

4. See Dewey's important conclusion to Chapter 2, "The Live Creature and Ethereal Things", in Art as Experience (LW 10: 39-41). Dewey works will be cited in the standard format of the critical ed.publish. by Southern Illinois University Press: EW (Early Works), MW (Middle Works), and LW (Later Works). 
Not only does this restrict the idea that all experience is inherently cognitive, it prevents any possibility of a "rationalistic" or "Hegelian" conception of pragmatism. Linguistic pragmatism misses the centrality of the "had" or "undergone" aspect of experience, an integral but ineffable dimension of our existential inhabitation of nature, a "generic trait", in Dewey's terms. This blindness leads to a neglect of understanding what Dewey means by "situation" and its pervasive qualitative horizon which is a condition of conscious rational thinking and pragmatic inquiry. In short, linguistic pragmatism loses the vast noncognitive dimension of human experience, the aesthetics of existence.

Experience is Culture. In spite of a lifetime explaining what he meant by "experience", Dewey is still read as somehow standing in the British empiricist tradition's assimilation of experience to "perception" and its derivatives (such as sense data, mental states, propositional content, etc.), i.e., something occurring in (or by means of) some entity called a "mind"5. "Experience" in Dewey's sense is not "perception" but adaptive existence, which in human existence takes on the form of culture. Even Brandom, who treats Dewey's view of experience in terms of the organism-environment relation as a mechanistic feedback loop (PP: 39-40), wants to focus on "the priority of the propositional" (PP: 3, 8-9). The meaning of "experience" for Dewey is "culture", not "perception" or something explicated in propositional units; it is primarily social and not a feature of a "mind" (as philosophy of mind likes to think of it). In fact, for Dewey, "mind" is another way of referring to "culture". "Mind" is what is passed on from one generation to the next and is the formative context within which individuals develop and by which they become communicative beings. It is the process of cultural communication, exemplified in education.

Language is Communication. Culture is the "Tool of Tools": "Language" for Dewey is just this process of communication. The key to understanding it is not to focus initially on propositions but on the fact that it calls for listeners as well as speakers and that both imaginatively see themselves from the standpoints of the others. The phenomenon of communication involves a dramatic form of imagination (unsuspected, as far as I can tell, by Wittgenstein) in which we take on the role of the other to determine the possible meaning of a symbol we may use. Language is this world of mutual symbolic participation, of shared experience. It is this view that lies behind Dewey's description of language as "the tool of tools". In other words, language is "culture" in the anthropological sense of the word, a shared symbolic life. Language is less a formal syntactic-semantic system than it is an interactive process of symbolic communication involving mutual imaginative copresence. "Language" can thereby include all modes of symbolic communication and so it, too, is another way of saying "culture". When Dewey describes language as "the tool of tools", he is not thinking of language as some "meta-instrument" (PP: 28) or some external

5. This desire to force the pragmatists into the traditional history of modern empiricism is reflected also when Robert Brandom interprets the pragmatists as constituting a "Second Enlightenment", pushing forward the light of reason in all dark corners and promoting a panscientistic agenda (PP: 35-36, 4043). To support this untenable claim, Brandom makes another, that Romanticism had no effect on the major pragmatists. This is simply untrue, especially of Dewey. See Goodman 1990 
piece of technology consciously created with a specific purpose. What he is saying is that all specific symbolic or tool-using actions depend on culture: i.e., technologies depend upon culture. Language as culture is what makes it the "tool of tools"; it is the condition of technologies. Insofar as linguistic pragmatism has not even raised its eyes to address a deeply cultural conception of experience and language, I do not see how its highly refined and strictly limited concerns about beliefs and propositions begin to approach a Deweyan conception of language as culture.

Linguistic Pragmatism vs. Cultural Naturalism. Thus I believe that the future of "pragmatism" lies in relocating it within "cultural naturalism" (the correct name of Dewey's philosophy) or what I call "ecological humanism". It lies in focusing on the idea of culture in the anthropological sense and not returning to "linguistic philosophy" as usual. It asks for a richer sense of human existence than to portray us as robotic knowing machines. The new Anglophone pragmatism is, I believe, a regression to the old habits of analytic philosophy and not any sort of creative growth of the classical pragmatic position. If we look at the pragmatic consequences of linguistic pragmatism, it means doing the same thing analytic philosophy has been doing for decades: talking about propositions and focusing on epistemology and philosophy of mind. Politically, however, it operates as an attempt to commandeer the resurgent interest in pragmatism and draw it back into the familiar hegemonic Anglophone conception of philosophy. Thus I not only defend retaining the use of the term "experience" (as "culture") but believe that it must be genuinely developed.

There is a lot of exposition of Dewey in what follows, but that is because the term "experience" is his more than anyone's among the pragmatists. It is Dewey who is accused by Brandom as well as by Cheryl Misak as being the "mistake", the "wrong turn", or "dead end" in their versions of the history of the movement $t^{6}$. Thus there is more than some point to spending time on Dewey. But I do not believe that is where we should stay - just begin. It is high time we started thinking about "philosophy of culture" rather than "philosophy of mind" and turned toward anthropology and semiotics rather than physics, neurology, or information theory. One could even speak of reviving the idea of a philosophy of symbolic forms. To that end I have made some developments elsewhere that I will briefly mention at the end of this essay more by way of illustration than substantive exposition of a new direction for developing pragmatism as an "ecological humanism" or "cultural naturalism".

\section{The Rebirth of Pragmatism}

It is difficult to realize that Richard Rorty's Philosophy and the Mirror of Nature made its appearance some thirty-five years ago. For someone of my generation, Rorty had been one of the younger standard bearers of "the linguistic turn" . As a

6. See (PP: 48 ff.), and Misak 2013.

7. Rorty's anthology, The Linguistic Turn (1967) was de rigueur and the "Introduction" - as we read it then - seemed to look forward to an indefinite future of linguistic philosophy. In retrospect, it seems full of the irony, doubts, and sense of faddish contingency that became explicit in Rorty's thought later on. Rorty's subsequent introductions to the famous collection make this clear. 
young philosopher and scholar working in the American tradition, Rorty's sudden appropriation of Dewey (and Heidegger) felt to me like the "Year of Jubilee" when all slaves would be set free. For in those days you couldn't mention Dewey or James in polite philosophical company, and Peirce was barely tolerated (at least, he was a logician!). As for Heidegger, how often did I hear "Heidegger is not a philosopher"8? The American Philosophical Association was not just dominated by analytic philosophy but had become a self-perpetuating analytic hegemony. This was not due to some accidental outcome but was a conscious ideological statement of what constituted "real philosophy". Philosophers of other persuasions "need not apply". Its control of the main organ of the profession meant replicating its type of philosophy throughout departments in the United States indefinitely. Thus arose the various "satellite" organizations like The Society for the Advancement of American Philosophy and the historical recovery of the work of Dewey, James and Peirce through critical editions of their works ${ }^{10}$. We tried to create an atmosphere in which philosophy could be done in the spirit of a community of inquiry and not as a confrontational jousting match. Suddenly, Rorty had not only veritably shouted out the names of Heidegger and Dewey, mentioning them in the same breath as that of the sainted Wittgenstein, but he called the whole analytic project and the march of scientific truth into question, raising the Specter of Relativism.

For me and those like me, it was a double-edged experience. Yes, it felt as if Rorty had opened all the windows of a hot, stuffy school on a bright early spring day, letting in smells of wet earth and new life mingled with a clean, cold wind from distant snows on mountains. But his breezy, slap-dash "scholarship" and the portrait of Dewey as a relativist were appalling. As the Rorty phenomenon burgeoned, it came to define the debate on what was and was not "pragmatism"11. For better or worse, Rorty had indeed opened up the "conversation" and "pragmatism" was no longer just a term for what fuzzy-minded American thinkers did in the olden days before the discovery of logical fire and Vienna Circle positivists, fleeing Hitler, brought its secret to America.

Now, it seems, there is a wealth of "pragmatists". Not only is there "pragmatism" but there are many subvarieties of "-isms" of pragmatism. Robert Brandom alone offers a

8. Bertrand Russell dismisses him with one quip in his historical picture book, Wisdom of the West (1964).

9. See Bruce Wilshire's incisive discussion of this issue in Fashionable Nihilism: A Critique of Analytic Philosophy (2002); see in particular ("The Pluralist Rebellion in the American Philosophical Association", Chapter 3: $51 \mathrm{ff}$.).

10. Aside from the beginnings of the critical editions of the works of Dewey, then James, then Peirce, Santayana, and, now, Royce, there were three highly important anthologies with weighty and insightful introductions by John McDermott: The Writings of William James (1967) The Philosophy of John Dewey (1973), and Josiah Royce: Basic Writings (1969). Mention should also be made of H.S. Thayer's monumental Meaning and Action: A Critical History of Pragmatism (1981) and Elizabeth Flower's and Murray Murphy's A History of American Philosophy (1977).

11. Why did Rorty even embrace this term? He had no concern with methods, inquiries, consequences. He found that things he said "sounded like" things Dewey said. But, with the appearance of Consequences of Pragmatism (1982), it was clear that the "consequences" were for determining conversational topics. 
dizzying assortment, ranging from "fundamentalist pragmatism" to "methodological pragmatism" to "instrumentalist pragmatism" to "semantic pragmatism" to "linguistic pragmatism" to "normative pragmatism". While the renewed interest is welcome and healthy, I find that a great deal has been sacrificed and what I hope to offer here, as summarized above, is a series of points that serve to divide "experientialist" pragmatists from the "linguistic" pragmatists. I think these points touch on matters so integral to what pragmatism - at least Deweyan pragmatism - is all about that I wonder if the use of "pragmatism" should be dropped by all for the sake of clarity. In PP, Brandom has a generous list of "pluses" that classical pragmatism offers, but he goes on to say "what one misses most in the pragmatists - at any rate separates them from us - is that they do not share the distinctively twentieth-century philosophical concern with language, and with the discontinuituies with nature [sic!] that it establishes and enforces" (PP: 55) 12 . Brandom wishes to retain "putting language at the center of philosophical concerns" and wants "understanding philosophical problems" to be in terms of "the language one uses in formulating them". Specifically, "lingualism" should be "a commitment to understanding conceptual capacities (discursiveness in general) in terms of linguistic capacities" (PP: 22). Philosophy becomes philosophy of language before it is philosophy of anything else.

I don't think the analytic pragmatists knew what they were getting into when they turned to pragmatism and, once they actually realize it, they will be appalled. "Isms" are dangerous things, anyway. They may sound like highly technical terms, but they are broad, impressionistic gestures at best and induce one to attack straw men. I think it is especially unfortunate that the term "pragmatism" has come to characterize "American philosophy" as a whole, especially for foreign students. The American philosophical tradition has many mansions, vibrant and rich ones besides pragmatism. Also, as noted above, to characterize Peirce, James and Dewey simply as "pragmatists" narrows the sense of their overall philosophical positions; it's rather like describing Aristotle as a "logicist". Does "pragmatism" begin to hint at Peirce's vast architectonic philosophy or his semiotic evolutionary cosmology? It by-passes James's "radical empiricism", which (he claimed) stood or fell apart from his "pragmatism", as well as his psychology and religious philosophy. And we have this from John Dewey in his eighties in a letter to Corliss Lamont, "I have come to think of my own position as cultural or humanistic Naturalism. Naturalism, properly interpreted, seems to me a more adequate term than Humanism. Of course I have always limited my use of 'instrumentalism' to my theory of thinking and knowledge; the word 'pragmatism' I have used very little, and then with reserves"13.

So, here, it is not really helpful to characterize "the pragmatists" by "pragmatism" either. But, if we must speak in the generalities of "isms" here, "pragmatism" it must be.

12. How could a naturalist profess to find "discontinuities with nature"? Dewey's own approach was to take nature as it came and if at some times and places it has language events, then that tells us something about nature. "Continuity" does not mean reduction but growth. It is evolutionary.

13. Dewey to Corliss Lamont, Sept. 6, 1940, cited in Lamont (1961: 26). 


\section{"The Intellectualist Fallacy" and a Noncognitive Approach to "Experience"}

One of the major "tacit presuppositions" (to use Whitehead's expression) that most of Anglophone philosophy inherited from the modern period was the idea that human beings were fundamentally knowers and therefore that the main problem of philosophy was the problem of knowledge. We were also subjects, specifically minds, set over against a world. Whatever else was happening to a subject (or mind), the subject was also "knowing". One simply wasn't in pain; one also knew one was in pain. The subject was a "knowing mind" and the question was how it knew, whether by ideas, impressions, sense data and a priori rules, mental states, or propositional attitudes, and so on. Brandom, for example, while recognizing that not all beliefs are explicit, nevertheless thinks of them as encapsulating "content" in terms of the role they play in the whole of all other beliefs; the same is true of desires (PP: 1920). Experience is about judging, the application of concepts or rules to which one is then committed rationally (PP: 2-3). This cannot lead to an infinite regress (rules for applying rules) but is grounded on beliefs as dispositions to act (PP: 13-14). For Brandom, this is "fundamental pragmatism": knowing that is based on knowing how (PP: 9). In spite of the "pragmatic" turn in placing emphasis on belief as action, it still has tacit propositional content that can be linguistically explicated. I think this is still a version of the assumption that all experience is about knowing ${ }^{14}$. All phenomena of human existence, or at least human mentality, whatever else they may be, are to be regarded in terms of their status as knowledge, as verbal knowledge. It is of utmost importance to realize that Dewey rejected this thesis from the very incipience of what became his mature position. This was the basis of his instrumentalism.

Although there are anticipations of Dewey's theory of inquiry in his writings from the mid 1890s on, the instrumental theory of knowing as inquiry is dramatically unveiled in the essays he contributed to his department's collective publication, Studies in Logical Theory (1903) ${ }^{15}$. Dewey's four essays carefully work out the view of thought as arising within life experience (which is concerned with other things than knowing) and terminating in it. Knowing is a reconstructive phase of experience; it is something actually done (not some behind the scenes mental operation or a general "condition for the possibility of knowledge"). Nor is it the whole affair; it is just an intermediary process. The implications of this account of inquiry are developed in "The Postulate of Immediate Empiricism" (1905), published just after Dewey's move to Columbia. It was not until he wrote the extended "Introduction" to Essays in Experimental Logic (1916) that he achieved the first fully developed statement his mature theory of experience ${ }^{16}$.

14. In fairness, Brandom protests against representationalism and the idea of content at the prepersonal level (PP: 12-13). But "each new episode of experience" is for him is a "perceptual judgment" that must be integrated into an evolving rational whole of commitments (PP: 2).

15. The essays are: "The Relationship of Thought and Its Subject-Matter", "Antecedents and Stimuli of Thinking", "Data and Meanings", and "The Objects of Thought"; they were reprinted in Essays in Experimental Logic (1916) and can be found in (MW 2: 296-367).

16. This introduction can be found in (MW 10: 320-65). 
The story of this development cannot be told here, obviously, but the key insight is that not all experience is experience-as-known and that knowing experience arises and terminates within experience that is not knowing. To affirm that all experiences are also knowing experiences is to commit what Dewey came to call "the Intellectualist Fallacy"17. Initially Dewey saw this point as the basis of his disagreement with absolute idealism, and so the essays in Studies in Logical Theory are directed against the now forgotten figure of Hermann Lötze. But he soon came to see it as the basis of his disagreement with the realists, including Bertrand Russell, and ultimately with most of the history of western philosophy. The explicit claim to equate what truly, really is with what is known goes back to Parmenides: "For it is the same: to know and to be" ${ }^{18}$. While the medieval period may have made the reality of God transcend our knowing, God knew the world and the human intellect approximated His knowledge as best it could. The moderns, too, made the known the criterion of being, with less modesty than the medievals. Homo cogitat, said Spinoza, which for him meant man could grasp the infinite and eternal essence of God or Nature. The post-Kantian idealists made knowing - especially as self-knowing - the constitution of reality, of Spirit's unfolding of its inner necessity. The naturalist version of this is that nature is whatever scientific knowing is. For example, Huw Price characterizes "popular naturalism" as "the view that in some important sense, all there is is the world studied by science"19. Brandom unveils his scientia mensura: "science is the measure of all things - of those that are that they are, of those that are not, that they are not" and sees this as a central commitment of the pragmatists "and their Enlightenment ancestors" (PP: 38-39). Quite the contrary: Dewey sees the equation of reality with the known as misguided and fruitless ${ }^{20}$. (And so his version of naturalism, cultural naturalism, must not be confused with this thesis.) His recently discovered uncompleted opus, written in his eighties, is a long diagnosis of the consequences of this assumption and the unfortunate "epistemology industry" that has flourished in its wake $^{21}$. So: it is important to be clear on this point because it diverges so much from the presuppositions of most Anglophone philosophers, including those who have read enough Dewey to think they understand him. They miss it by a mile 22 .

Why did Dewey come to this conclusion? Again, the answer for this is found in his essays for Studies in Logical Theory. Recall the context: Dewey had been an

17. See Experience and Nature (LW 1:28) and The Quest for Certainty (LW 4: 232). See also "Beliefs and Existences" (MW 3:83-100), "The Intellectualist Criterion of Truth" (MW 4: 50-75) and "Brief Studies in Realism" (MW 6:103-22).

18. DK B3; my translation.

19. Price (2013: 4-5)

20. Neither James nor Peirce would accept this either. James's The Will to Believe and Essays in Radical Empiricism cannot in any way be said to submit to the thesis. Peirce may have said reality (the general universe of Thirdness or laws) would be discerned by inquiry in the long run, but this did not apply to existence (the domain of Secondness) or to those pure qualitative possibilities of the domain of Firstness. 21. See John Dewey, Modern Philosophy and Unmodern Philosophy (2012). The phrase "epistemology industry" is most famously found in "The Need for a Recovery of Philosophy" (MW 10: 23) but can be found as early as 1897 (EW 5:29).

22. As one analytic colleague, sitting in on my Dewey seminar, said when this point was made, "Oh, so that's what is wrong with him!" 
articulate spokesman for absolute idealism since his early essays of the mid-1880s and Psychology of 1887. But during his tenure as chair of the Department of Philosophy, Pedagogy and Psychology (1893-1903) at the University of Chicago, his focus was on the nature of education - on the actual process of learning and not the "justification" of knowledge assumed to be true. Moreover he had been highly influenced by William James's The Principles of Psychology, which he encountered in the year of its publication, 1890. He was particularly impressed by James's functionalistic view of mind as a selective "fighter for ends" and his view of experience as already coming whole, something in need of analysis and clarification, rather than the traditional empiricist view of experience constituted by swarms of atomically discrete impressions in need of some active power of mind to weld them together into a world ${ }^{23}$. James had removed at a blow the spectator theory of consciousness and the need for any a priori synthetic power as a condition for experience. Dewey had begun to understand thinking - thinking not thought - as a process in the lifeworld and not its underpinning. Moreover, James had described what he called "The Psychologist's Fallacy": the psychologist, standing "outside the mental state that he speaks of", as James puts it, assumes that the state "knows" its object as he does. In other words, what for the psychologist is the outcome of cognitive analysis is assumed to be the original condition of the experience: hence it "really" was a knowing experience all along ${ }^{24}$. Dewey generalized this criticism: philosophers, treating everything from the standpoint of analytical, reflective experience, i.e., as known, assume that all experience originally is as it is known in inquiry; results attained by selection and analysis are substituted for the complex, full-bodied and richly ambiguous experience. It is not that the object as known is made up out of thin air; it is not. But it is a selective refinement of experience, selecting some features and disregarding others ${ }^{25}$.

The first of the four essays Dewey contributed to Studies in Logical Theory, "The Relationship of Thought and Its Subject-Matter", begins by noting that "no one doubts" that reflective thought is secondary, that is "it comes after something and out of something, and for the sake of something" (MW 2: 298). Dewey is referring here to "reflecting" as a part of ordinary life: trying to negotiate a new town, remembering where a lost item might be, wondering how to repair a broken friendship. Dewey is not thinking of a "mind" that is cogitating, much less generating propositions, behind the scenes, so to speak. Dewey begins with the concrete phenomenon of inquiry. To do so, however, plunges one into "the very heart of the logical problem; the relation of thought to its empirical antecedents and to its consequent, truth, and the relation of truth to reality" (MW 2: 298). From the commonsense, practical attitude, there is no such difficulty. "The antecedents of thought are our universe of life and love; of appreciation and struggle" (MW 2: 298). In these situations the function of thinking is to mediate, which, if successful (and if it really resolves the problem and doesn't

23. See James 1890 I: 141, and Chapter IX.

24. James (1890, vol. I.: $196 \mathrm{ff}$.).

25. This explains why Dewey's view of knowledge does not say (as Russell accused him of saying) that we cannot really know the world; the world prior to being known is know-able in certain respects, but it is "-able" in a variety of other ways as well. Its existence is not at issue; the "external world" does not have to be "proved" because it is not "external" to begin with. 
just satisfy subjective desire), marks the cessation of the process for the while. There is a "rhythm of direct practice and derived theory" (MW 2: 299). The primary phase is "prediscursive" as the final phase is postdiscursive. The "discursive phase", which is a transformational process and not something simply propositional, comes in between. Thus, one problem with linguistic pragmatism is that it attempts to make an intermediary function the whole picture; it was the point of Dewey's revolution to put the role of inquiry - as process - in its place ${ }^{26}$.

Dewey contrasts this "organic" view of thinking as part of the life-process with epistemology, which tries to deal with "thought at large" and its relation to "reality at large" (MW 2: 303). Dewey sees continuity between the thinking of "the plain man" (as he likes to say) and scientific inquiry; "The fundamental assumption is continuity" (MW 2: 305-06) $)^{27}$. The latter ends in a cul-de-sac, "a problem which can be discussed only in terms of itself" (MW 2: 308). The former takes seriously the idea of a "natural history" of thinking and inquiry, a "logic of experience", with the various distinctions of logic formed in the context of inquiry as "organs of adjustment"; the latter rejects any temporal or genetic issues as having bearing on its formal conception of logic and knowledge (MW 2: 309, 313, 304).

In the second essay for Studies, "The Antecedents and Stimuli of Thinking", Dewey gives an early description of what becomes a central term in his thought: "situation". This is also relevant for grasping the basis of his noncognitivism. Not only is our involvement with the world prior to a specific inquiry, it is also an involvement that is not grounded on a basic subject-object distinction at the outset. A situation is a condition for inquiry because it itself is not inquired into at the time. Aspects or features of it may come up for inquiry; aspects or features of it may be the settled outcomes of prior inquiries. But none of this makes it intrinsically cognitive. The fact that it is analyzable does not mean it is already analyzed (MW 2: $326 \mathrm{ff}$.). It is the situation as a whole that is the condition and stimulus to thinking (MW 2:328). The situation, in other words, is not an aggregate but a dynamic continuity ${ }^{28}$. "All distinctions discovered within thinking", says Dewey, "come within the thoughtsituation as growing out of a characteristic antecedent typical formulation of experience" and aim at "the restoration of a deliberately integrated experience from the inherent conflict into which it has fallen" (MW 2:336). This applies to the subjectobject distinction as well.

Dewey expands James's view of selectivity in the stream of thought to refer to the situation of inquiry: certain features are selected as important and having bearing.

\footnotetext{
26. Brandom acknowledges a prediscursive background, our dispositiional beliefs, but treats them merely as the predecessors of verbally explicit articulations. See (PP: 12-13).

27. This is eloquently put forth many years later in Logic: The Theory of Inquiry, Chapter 4, "Common Sense and Scientific Inquiry".

28. Thus, although Brandom wishes to characterize his "fundamental pragmatism" by stressing the need for an "implicit background of not explicitly conceptual abilities" made up of "potential beliefs" that are the condition of explicit intentions and beliefs with content, he still regards this background as constituted by specific "know-how" abilities that can be expressed linguistically. He is interested in this background only in terms of cognition, of knowing that as a result of knowing how. This conception of the background is very far from what Dewey calls "the situation". See (PP: 65-67).
} 
As Dewey will say later, "data" being selected out are really "takens" rather than "givens" 29 . They are given "to further thought" (MW 2: 343). But there are no "readymade antecedents". Over against these selected features, "There is always something unquestioned in any problematic situation at any state of its process" (MW 2: 339). The process also involves contrasting what are taken as data from the operations and inferences that "thought" makes. The two are functionally distinguished, like building material and building tools (MW 2: 364). The test of thought is achieving a resolved situation, "the unity of the experience actually effected. The test of the validity of thought is beyond thought" (MW 2: 367). And so by giving a functional analysis of the process of inquiry, Dewey avoids transposing the objects and their meanings that are selectively abstracted from the more complete situation back into the original situation as they have become determinate in the process of knowing. This is Dewey's version of James's Psychologist's Fallacy. The pre-known world is a matrix out of which any variety of selections can be made. To pronounce some particular selection as what it "really" is then results in denying full reality to the others so that, at best, they become "appearances".

By 1905, Dewey was ready to draw a metaphysical conclusion from his new model of inquiry. As I have discussed elsewhere, "The Postulate of Immediate Empiricism" was a highly controversial essay which even today is not well understood ${ }^{30}$. The essay appeared amid the "realist revival" as well as in the wake of James's first articles on radical empiricism. In a sense, Dewey's essay is a response to both. He accepts James's view of experience as a living whole from which aspects and concepts are abstracted and he extends this to a new view of reality that rejects the radical separation of the subject, and all that comes with it, from the world. In Dewey's later language, when one is in doubt, "doubt" is not a subjective state but a feature of "the situation". Aligning himself with that "movement" called "radical empiricism, pragmatism, humanism, functionalism", Dewey adds his own newly-christened "immediate empiricism". "Immediate empiricism postulates that things - anything, everything, in the ordinary or non-technical use of the term 'thing' - are what they are experienced as" (MW 3: 158). To "describe a thing truly" one must "tell what it is experienced as being". To interpret "experienced as" into "known as" is the problem. "This is the root paralogism of all idealisms, whether subjective or objective, psychological or epistemological" and "if not the root of all philosophic evil, at least one of its main roots" (MW 3: 159-60).

If one retains a subject-object dichotomy underlying this process beforehand, then this sounds like pure subjective relativism, for "experience" will be understood as "in a subject" or "in the mind". But what Dewey intends is to stress all the ways in which some "thing" can be involved in our interactions ("experience") apart from one dominating concern like knowing. A horse may be a means of transportation, a beloved companion, a beautiful creature, and so on. None of these are instances of knowing. Any of these relations may become occasions for inquiry insofar as they become problematic: As a parent, is the horse too temperamental and unsafe for my

29. The Ouest for Certainty (LW 4: 142-43); the chapter is a mature summation of the thesis of the essays for Studies in Logical Theory.

30. See my "The Aesthetics of Reality", in The Human Eros (2013). 
child to ride? As a caring owner, is the responsible thing to keep a sick horse alive or have it put down? As an artist, did my painting do justice to its beauty? All these are situations in which there is indeterminacy and doubt; they involve operations of inquiry to be resolved. Dewey's point is that all these ways of being-in-relation-tothe-horse, including the mode of inquiry or knowing, are real. But one "real" is not privileged over the others. Thus "reality" takes on a plurivocity with a variety of "as-structures"; these cannot all be reduced to the univocity of "as-known". Nor does this mean that one sort of noncognitive interaction, say one of aesthetic appreciation, cannot turn into a situation in which inquiry, and so, possibly, knowledge, emerge. A veterinarian enjoying riding a horse may notice something that might indicate a disease and begin to examine the animal to determine the result. The outcome of diagnosis would be an instance of knowing because it is the result of inquiries initiated by a tensive or problematic aspect of a situation. But, also, knowing situations can transform into aesthetic ones or other sorts of noncognitive interactions. The main idea is that the matrix of inquiry, the lifeworld, is largely noncognitive.

In Experience and Nature, Dewey expands this idea of the noncognitive dimension of experience to characterize the qualitatively immediate and ineffable aspect of existence as existence. He describes certain "generic traits" of nature, the primary ones being "doing" and "undergoing". Undergoing is what Dewey also calls "having", the qualitative, determinate immediacy of existence as the outcome of a history of events ${ }^{31}$. It is the brute thatness of any experience ${ }^{32}$. Dewey observes that "in every event there is something obdurate, self-sufficient, wholly immediate, neither a relation nor an element in a relational whole, but terminal and exclusive" (LW 1: 74). There is this aspect to any experience, to any moment of interaction. And Dewey insists that it is ineffable:

Immediacy of existence is ineffable. But there is nothing mystical about such ineffability; it expresses the fact that of direct existence it is futile to say anything to oneself and impossible to say anything to another. Discourse can but intimate connections which if followed out may lead one to have an [experience]. Things in their immediacy are unknown and unknowable...because knowledge has no concern with them. (LW 1: 74) $)^{33}$

Any system, he adds, materialistic or idealistic, that renders reality as a pure system of relations has committed the Intellectualist Fallacy; it has taken knowing, which is concerned with relations, as the key to all existence. Thus, for Dewey, all experience

31. See Experience and Nature (LW 1, Chapter 3). There is a reason Dewey presents this generic trait of qualitative immediacy before that of relation, as revealed in doing, and knowing, the theme of Chapter 4. In "The Need for a Recovery of Philosophy" Dewey says, "Experience is primarily a process of undergoing: a process of standing something; of suffering and passion, of affection, in the literal sense of these words" (MW 10: 8). Brandom wholly neglects this aspect of experience for his emphasis on doing: "Experience is work: the application of force through distance. It is something done rather than something that merely happens" (PP: 7).

32. Remember to read "experience" mainly as existence, the way the world is as we are in it, and not perception.

33. The passage has "have an existence" rather than "have an experience"; I believe this is a mistake that was not caught. Dewey constantly speaks of "having an experience" and, to my knowledge, never anywhere else of "having an existence". 
insofar as it is undergone has this ineffable immediacy; it cannot be regarded as something inherently cognitive or discursive or relational.

This had aspect is the basis for aesthetic or consummatory experience, for immediacy can be immediacy of meaning, meaning as $h a d^{34}$. Some experiences as had are simply mute, like stubbing one's toe in the dark. But others that are outcomes of processes in which intelligence has been at work can embody the meaning of the history in its had, undergone, or immediate aspect. Here, a given moment of listening to music carries with it the sense of the composition that has been already played; the musical phrase has poignancy, longing, searching, or joyful resolution as part of its felt quality. The present phrase develops and anticipates. This is as true of intellectual or practical activities as of those that are explicitly artistic. Dewey's point is that the aesthetic "having" of meaning is not also an instance of knowing. The mistake of Platonic and Aristotelian metaphysics, according to Dewey, was that it took the aesthetic having of meanings and mistook them for objects of intuition or rational insight, i.e., as moments of knowing. Be that as it may, Dewey's point is that the noncognitive is one of the features of transactional existence or nature. Thus, any attempt to "improve" Deweyan pragmatism by reaffirming that all experience is cognitive would not be an improvement; it would be to invert it completely and turn it into precisely the sort of thing Dewey repudiated from the start. It would be an instance of the "Intellectualist Fallacy".

The noncognitive also functions in inquiry or cognitive experience. The idea of the ineffable not only constitutes a central feature of Dewey's naturalistic metaphysics but contributes to a more sensitive analysis of all inquiry - all experiences of knowing as underpinned and fundamentally guided by noncogntive dimensions of experience, by the "pervasive qualitative whole" or "qualitative thought", as he came to refer to it. This is best set forth in an essay of 1930, "Qualitative Thought". Our world of our existence, Dewey says, "is preeminently a qualitative world" in which "thought is definitely regulated by qualitative considerations" (LW 5: 142). "The qualitative dimension of any experience is due to its being in a situation; whatever the internal complexity, a situation is dominated and characterized throughout by a single quality" (LW 5:246). This is not some categorized or labeled quality, but one that is unique. The "selective determination and relation of objects in thought is controlled by reference to a situation - to that which is constituted by a pervasive and internally integrating quality, so that failure to acknowledge the situation leaves, in the end, the logical force of objects and their relations inexplicable" (LW 5: 246). It was Bertrand Russell's failure to understand this that made him misunderstand Dewey's Logic: The Theory of Inquiry, as Dewey notes in his response to Russell. Dewey's comments provide a handy and pertinent reply to persistent misunderstandings by others as well ${ }^{35}$.

34. This topic is the central theme of my John Dewey's Theory of Art, Experience and Nature: The Horizons of Feeling (1987). The idea is prefigured in James's doctrine of the feeling of relations in The Principles of Psychology: "We ought to say a feeling of and, a feeling of if, a feeling of but, and a feeling of by, quite as readily as we say a feeling of blue or a feeling of cold' James (1890 I: 245-46). It subsequently developed into James's radical empiricism.

35. See Schilpp (1951: 544-49). 
The situation is that ultimately to which thought refers, though the situation "as such is not and cannot be stated or made explicit" (LW 5: 147). It nevertheless constitutes "the universe of discourse" within which language can make sense and it "controls the terms of thought" (LW 5: 247). In other words, for Dewey's theory of experience, the noncognitive, qualitative dimension is present in the cognitive and ultimately guides it even in our most logical moments.

The noncogntive is thus the basis of Dewey's instrumentalism and forms a key dimension of his metaphysics of nature and underlies his theory of logic. This is not a vague or undeveloped aspect of an otherwise rugged scientific naturalism; it is the core of Dewey's conception of experience. One may disagree with it, but one should not try to appropriate it and "improve" upon it by forcing it to be the very theory it rejects. Dewey's view, while certainly controversial, must stand in stark contrast to any form of "pragmatism" that believes that cognition is ubiquitous, that any belief can be translated into an action and that into explicit proposition. It rejects in principle the idea of an evolving rational whole of beliefs that is the whole story. If one is going to adopt linguistic pragmatism, it will be at the cost of all that is contained in Dewey's concept of experience. And with that goes, I believe, most of what makes us human.

\section{Experience is Culture}

As I have noted, one of the persistent causes of critical misinterpretation of Dewey is the understanding of his use of "experience" as if he were writing in the British empiricist tradition, i.e., of it being understood as "perception" or "idea" or "mental state" and so on, i.e., something "in" a "mind"36. Dewey is quite explicit that he never held this view, and he certainly did not in his "pragmatist" period. "The Postulate of Immediate Empiricism" opened the door to understanding experience as a situated event, as a way of existence that is primarily concerned with the relationships of human beings to the environment, inhabiting nature as social, communicating beings. In other words, "experience" in Dewey's work is synonymous with "culture" as the term is used in anthropology: the structured practices and symbol systems by which human beings exist together as communities in the world and not as remote, individual mentalistic observers of sensations or holders of propositions. In a document meant to accompany a course taught in 1922, Syllabus: Types of Philosophic Thought, Dewey begins,

The word "experience" is here taken non-technically. Its nearest equivalents are such words as "life", "history", "culture" (in its anthropological use). It does not mean processes and modes of experiencing apart from what is experienced and lived. The philosophical value of the term is to provide a way of referring to the unity or totality

36. This way of thinking derives ultimately from Descartes who presents the novel doctrine that ideas are "modes" of the substance res cogitans just as bodies are "modes" of the substance res extensa. Locke (somewhat inconsistently) adopts this manner of speech, emphasizing that the "idea" is now no longer the form of an object - its "objective" or substantial structure - but a "representation" of it, a modification or mode of the mind, something that "the mind" observes directly or "mentally", as part of its own subjective status. See Essay Concerning Human Understanding (II.viii.8 and IV.i.1). 
between what is experienced and the way it is experienced, a totality which is broken up and referred to only in ready-made distinctions or by such words as "world", "things", "objects" on the one hand and "mind", "subject", "person", "consciousness" on the other. Similarly "history" denotes both events and our record or interpretation of them; while "events" include not only the acts and sufferings of human beings but all the cosmic and institutional conditions and forces which in any way whatsoever enter into and affect these human beings - in short, the wide universe as manifesting itself in the careers and fortunes of human beings. (MW 13: 351)

Dewey had been entirely clear about this in both versions of the first Chapter of Experience and Nature ${ }^{37}$. Noting that the meaning of "experience" has two incompatible sources (the scientific empirical method and "introspective psychology") and rejecting the latter, the 1925 version begins with "coarse and vital experience" that is "a thing of moods and tenses" (LW 1: 367). This is what the artist as well as technician engages, whereas the philosopher only too often "substitutes a dialectical development of some notion of experience for an analysis of experience as it is humanly lived" (W 1: 367). Dewey adds, "we mean then by experience something at least as wide and deep and full as all history on this earth" (LW 1:370). It is "the whole wide universe of fact and dream, of event, act, fancy and meanings, valid or invalid" (LW 1: 371). In the 1929 version, experience is synonymous with "its congeners, life and history" so that "it includes what men do, and also how men act and are acted upon, the ways in which they do and suffer, desire and enjoy, see, believe, imagine in short processes of experiencing" (LW 1: 18). Both Chapters introduce what Dewey calls "the denotative-empirical method", which is something that philosophers in particular should practice - the tracing back to primary, lived, existential situations in the world of the developed abstractions with which philosophy must deal. It is a way of avoiding the temptation to commit the Intellectualist Fallacy. It includes an awareness of cultural history, as Dewey's running analyses of ancient and modern philosophy in the book well illustrate. This view of experience also accounts for the frequent references to the work of anthropologists in the book, not least of whom was Dewey's famous colleague at Columbia, Franz Boas.

In his advanced old age, however, Dewey worked at drafts for a new introduction to Experience and Nature, one that would emphasize the role of cultural history even more. But he also entertained the thought of dropping the word "experience" altogether. "Were I to write (or rewrite) Experience and Nature today I would entitle the book Culture and Nature [...]. I would abandon the term 'experience' because of my growing realization that the historical obstacles which prevented understanding of my use of 'experience' are, for all practical purposes, insurmountable. I would substitute the term 'culture' because with meanings as now firmly established it can fully and freely carry my philosophy of experience" (LW 1:361). Dewey underscores that he means "culture" in its full anthropological sense and not "its Matthew Arnold sense" (LW 1: 362).

37. For a discussion of these two versions - and why the second was so much more misleading than the first - see my essay "Dewey's Denotative-Empirical Method: A Thread through the Labyrinth" in The Human Eros (2013). 
Attention should be drawn here also to a significant essay published two years after Experience and Nature, "Philosophy and Civilization", an essay that also gave its name to a collection of Dewey's choice articles that appeared in 1931. Dewey argues that the relationship of philosophy to culture is "intrinsic"; this includes contemporary philosophy which operates under the illusion that it is "emancipated from the influence of that complex of institutions which forms culture" (LW 3: 3). Philosophy does not just "happen" to have a history. "Meaning is wider in scope as well as more precious in value than is truth, and philosophy is occupied with meaning rather than with truth", Dewey says (LW 3: 4). Truth is important, but it cannot claim the whole field of meaning any more than cognitive experience could be taken to characterize all experience. Indeed, "truths are but one class of meanings" and beyond them there "lies the ocean of meanings to which truth and falsity are irrelevant" (LW 3:4-5). "In philosophy", adds Dewey, "we are dealing with something comparable to the meaning of Athenian civilization or of a drama or a lyric" (LW 3: 5). Human existence is mainly lived in the world of meaning, of imagination. "Imagination" here is not the individual power of fantasy but the cultural world of symbol and history. It is what gives definition to the idea of living not merely biologically but as member of a culture in a moment of its history, something that may shape not only what one thinks and believes but how one engages such physical basics as sexuality. If philosophy is to have an intelligent role in cultural direction and even transformation, it must not only be aware of history but understand itself as historical in terms of culture, not just "the history of ideas" ${ }^{38}$. Human existence is historical and cultural; this is the lifeworld from which philosophy springs and it does not escape those conditions. The question is whether a philosopher acknowledges or represses this ground.

Thus any discussion regarding the use of "experience" in connection with "pragmatism" needs to face the fact that we are not talking about objects conjured up by philosophical abstractions, be they mental states or propositional attitudes; we are talking about the ways in which groups of human beings inhabit the earth through a shared symbolic life. The problems of reference would have to be translated into issues such as how an atl-atl or spear-thrower "refers" to bison, how a canoe "refers" to water or how a plough "refers" to wheat. The philosopher should be thinking less about speaking a language even more removed from primary experience and more about how well his or her thinking has remembered that primary world of embodied cultural existence. The hope would be that the Deweyan philosopher would endeavor to be somewhat literate in some of the world's cultures, especially preindustrial and archaic cultures, and see that as more important than thinking about computers and neurology.

Thus, one of the major issues that divides "us" (experiential pragmatists or cultural naturalists) from "them" (linguistic pragmatists) is that "they" think we are holding

38. It was some fifty years ago that Herbert Marcuse critiqued Anglophone philosophy in terms of its replication of patterns of industrial capitalism (especially as "pure research" by productive individuals leading to an aggregate of "knowledge" as commodifed "wealth"). But of course, refusing to see philosophy historically or culturally, Anglophone philosophers could not see how they replicated in praxis the theoretical commitments of the culture of capitalism. See One Dimensional Man (1964: Chapter 7). 
on to some archaic piece of epistemology when we have dropped epistemology altogether and the "intellectualist" view of experience that comes with it and embraced instead an existentially embedded view of cultural existence that turns toward life, the lived body, culture and history. With this comes a different form of philosophical praxis than that esteemed by the Anglophone tradition. All debates will be pointless misunderstandings until this is recognized. By "experience" we mean how people live in the world, how they inhabit nature together.

\section{Language as the "Tool of Tools"}

Brandom believes that one of the things that separates "us" (the linguistic pragmatists) from "them" (the experiential pragmatists) is that classical pragmatists "do not share the distinctively twentieth-century philosophical concern with language" (PP: 55). I suppose one other way of looking at it is that classical pragmatism had other concerns in addition to that and had not come to the narrow thought that all problems in philosophy were linguistic ones or that philosophy itself might be a product of the misuse of language. But Brandom picks on a very central idea of Dewey's, that language is "the tool of tools", and so thoroughly inverts its meaning that it indicates, I believe, just how deep the difference goes between "them" and "us". Brandom does not like thinking of language as "the tool of tools" because, he says, it is a too narrow, a too utilitarian a view of language, as if language had "a purpose" or set of purposes like a Swiss Army knife ${ }^{39}$. This view would make Dewey's theory of language an extension of way Locke characterizes language in Book III of his Essay: men invent language with full reasoning powers beforehand and the social ability to make agreements on what terms should stand for. Brandom is right that we don't stand outside language like that - and Dewey more than agrees. While Brandom sees the "language as tool" metaphor linking pragmatism with the later Wittgenstein and the early Heidegger, he rejects the idea that it is a "mere tool", something purely external, a device with a set of specific conscious purposes behind it.

In a spirit of generosity, Brandom tries to find some positive things to say of Dewey's view of language: (a) it acknowledges all the different kinds of "tools" language may have and their many purposes; (b) tools often "refer" to each other so that using one means using the others; (c) this view introduces a "normative" dimension insofar as a tool is supposed to perform a task; (d) tools are "more or less successful" and so there is a sliding scale of performance; and (e) a tool may perform well in some areas and less so in others, so it has a "muiltidimensional" aspect. "What I object to is the idea that language as a whole is to be understood in terms of its being

39. Brandom completely misunderstands instrumentalism, describing it as the satisfaction of subjective desire in which the means is regarded as derivative and external. See (PP: 72-77). This is a complete inversion of Dewey's analysis of the means-end relation and in fact is precisely the view he argued against: "many critics take an 'instrumental' theory of knowledge to signify that value of knowing is instrumental to the knower [...]. But 'instrumentalism' is not about personal disposition and satisfaction in knowing, but about the proper objects of science, what is 'proper' being defined in terms of physics" (LW 1:121). See also Dewey's critique of utilitarianism in Human Nature and Conduct (MW 14: 133227). 
for something, in terms of its point being to serve as a means for the pursuit of ends" (PP: 79-80). Language doesn't help us pursue our goals, insists Brandom, it makes those goals possible - so this sort of "pragmatism" "gets the essence of the linguistic precisely backwards" (PP: 80). Of course what has been gotten backwards is how pragmatists think of the means-end relation, Brandom confusing it with the dualistic, utilitarian view pervasively critiqued in the works of Peirce, James, and especially Dewey ${ }^{40}$. And what has been missed altogether is what Dewey does mean by the "tool of tools" characterization of language.

Since this is the key point whereby Brandom thinks a call for a "linguistic pragmatism" is warranted, I want to examine Dewey's "tool of tool" metaphor, especially since I do not think it is hard to understand - providing one has read at least Chapters 4 and 5 of Experience and Nature. Dewey presents his discussion of communication - a more inclusive term than "language" - in the fifth Chapter of Experience and Nature. It has been preceded by Dewey's description of the "denotative-empirical method" (Chapter 1) mentioned above, his view of existence as a rhythmic process of the stable and precarious (Chapter 2), the radical "had" or qualitatively immediate, actualized, undergone aspect of existence (Chapter 3) and the active, projective, engagement with the world in terms of possibility through mediation by "tools" (Chapter 4). By "tool" Dewey means anything that transcends immediacy whereby human beings engage the world in terms of possibility and not realized finitude. It is not about an antecedently given subjective desire. A tool "is intrinsically relational, anticipatory, predictive. Without reference to the absent, or 'transcendence', nothing is a tool" (LW 1: 146). Thus a tool is anything that exists in the present but is used as a relation to something that is not present. It orients our existence toward possibility and that is what action is. This is true of symbols, language, concepts as it is for "tools" in the more physical sense, hammers, atl-atls, bows, or canoes. It is by means of this orientation toward possibility that human experience begins to take on meaning through relations so the contours of nature begin to show themselves. This is the birth of imagination as well as of intelligence. Tools indicate possibilities in the present so that those possibilities can be operative meanings in the present. Through making possibilities immanent, values can present themselves and choices be made. A door may be physically present and so abstractly be a possibility of leaving a room. But if it is not known to be present - if it is hidden in some way that possibility is not operative as a meaning in the present. The primary problem of intelligence is making possibilities present. Imaginative intelligence, in other words, enlarges the present situation to include some of its possibilities as meanings. This is the theme of the fourth Chapter of Experience and Nature.

In Chapter 5, "Nature, Communication, and Meaning", Dewey is ready to discuss the transformation of human existence that came with symbolic behavior, constituting a new "plateau" of natural existence, as he describes it later on ${ }^{41}$. Citing Franz Boas,

40. Dewey explicitly critiques the view of means that Brandom attributes to him at (LW 1: 134).

41. See Chapter 7, where Dewey presents the emergentist aspect of his metaphysics; nature is creative process for Dewey and so if nature produces living beings when before there were none or communicating beings where before there were none, he simply acknowledges that this indicates some 
Dewey comments that anthropologists list using tools and having language as two key features of human behavior. He goes on:

"Utensils" were discussed in the last Chapter, in connection with the useful arts and knowledge, and their indispensable relation with science pointed out. But at every point appliances and application, utensil and uses, are bound up with directions, suggestions, and records made possible by speech; what has been said about the role of tools is subject to condition by language, the tool of tools. (LW 1: 134)

This is the passage that makes Brandom infer that Dewey is thinking of language in the same way one might think of a hammer - something designed with a specific purpose in mind whereby it can be evaluated as "doing its job" well or ill. The opposite is the case. What Dewey is saying is that language is the condition of toolusing behavior in the more mundane sense. Language is the "tool" - the condition of the possibility - of other more specific tools being made or used at all. It is not "one big tool" like all the little tools. Without language (primarily understood as communication) no other "tools" could come about. In other words, Dewey is once again pointing to culture. Nor is it just that having a "means" of communicating allows us to use other things as tools, as Locke thought. It transforms the kind of being we are; it allows us to participate in a shared life of meaning and value; it is the basis for our having a sense of self and sense of other. Dewey makes this explicit, repeating the very phrase:

As to be a tool, or to be used as a means for consequences, is to have and to endow with meaning, language, being the tool of tools, is the cherishing mother of all significance. For other instrumentalities and agencies, the things usually thought of as appliances, agencies, and furnishings can originate and develop only is social groups made possible by language. (LW 1:146)

So, given that Dewey is not thinking of language as something "external" whereby we manipulate things, we should look closely at how he describes "communication". Dewey tells a humble story of A making a request of B to bring her a flower. Dewey is sensitive to the social and behavioral requirements for anything to be interpreted as "pointing". What is needed is that B must see himself from A's point of view, both in relation to the flower and to him. He "responds to the thing from the standpoint of A" (LW 1:141). He cannot just see the flower ego-centrically but as it may function and as he may function - in A's experience. He must see the situation in terms of its relations of possibilities and imagine which of those are at play. The same is true of A's attitude toward B; she must see herself from B's point of view if she is to indicate desire for the flower. "Something is literally made common in two centres of behavior.

of the things nature can do. Nature is what it does - what it has done and what it may do. Possibilities are part of nature. Thus Dewey has no need, as I see it, of what Brandom designates as the "leverage question" - how language comes to be. For Dewey that is a scientific question. But in any case, we do not "leverage" ourselves out of nature. See (PP, $28 \mathrm{f}$.). Brandom betrays a constant attitude that reason is somehow apart from nature in his appeals to Kant, "the mother of us all", as he likes to think. 
To understand is to anticipate together" (LW 1:141) ${ }^{42}$. More technically, A, in making the request, must put herself in B's position and use that as a way of interpreting what gesture she should make - interpreting her own gesture from the standpoint of the other. This is a sort of imaginative experimentation to try to predict how another might interpret our own actions; it is crucial in determining how we understand our own meaning. So, too, B uses his perspective of himself from A's position as a way of determining the meaning of the actions he will perform. This is what is involved: a mutual imaginative understanding of the situation from the standpoint of the other to come to a meaningful form of conduct for oneself; one realizes one is in a social communicative situation because of the mutual meaning of the symbols or gestures. There is, as it were, shared imaginative space ${ }^{43}$. Though Dewey does not mention it, one could add to this account the fact that each member, A and B, will be aware of the other being aware of the situation; there is recognition of what I have called "mutual alterity" 44 . In other words, a genuine "we" emerges, and so, therefore, an "I" and "Thou" can emerge as well ${ }^{45}$.

Dewey is also clear that "language" is not a "thing" like a formal system - not even a thing that can be divided neatly into syntactics, semantics and pragmatics. Parts of it may be so analyzable: these may be functional distinctions of use in inquiry into language. But the first and foremost aspect of language is that it involves hearers as well as speakers. I find it more than curious that our century of linguistic philosophy has produced very little on the subject of listening. And listening of course involves attentiveness, acknowledgement of an other, emotional resonance, reflective insight and an awareness of the unsaid, and perhaps of the unsayable. Thus the emphasis is upon communication as a process of mutual listening so that response is response to the listening: "The heart of language is not 'expression' of something antecedent, much less the expression of antecedent thought. It is communication; the establishment of cooperation in an activity in which there are partners, and in which the activity of each is modified and regulated by partnership" (LW 1: 141) ${ }^{46}$.

On a final note, language for Dewey is another way of saying "culture" along with "experience" and "mind". Brandom even quotes a passage from Logic: The Theory of Inquiry that makes this explicit, without, as far as I can tell, realizing it. The passage Brandom quotes says, "Language in its widest sense - that is, including all means of communication, such as, for example, monuments, rituals, and formalized arts - is

42. Here, too, Brandom actually quotes a passage from Dewey's Logic: The Theory of Inquiry that briefly discusses this aspect of communication, but as far as I can tell he makes nothing of it. See (PP: 28-29)

43. One might think of it as a game - the game of dialogue - which is the basis of other "language games". I find it a bit sad that when Wittgenstein came to think of language games his first thought turned to someone giving orders and people following rules. I am unaware he ever gave attention to imagining oneself from another's point of view.

44. See "Eros and Spirit", in The Human Eros (2013: 409-13).

45. This theory of symbolic interaction was developed by both Dewey and his former colleague at Chicago, George Herbert Mead. Mead's account, available as Mind, Self, and Society (1950), is more complex and nuanced than Dewey's. This aspect of Mead's theory was largely neglected by Charles Morris, his student and author of Signs, Language and Behavior (1946), which became so influential in the Anglophone efforts to understand pragmatism. See (Chapter II: 5) for his discussion of Mead.

46. In the twentieth century only Buber, Gadamer, and Levinas really spoke to this issue besides Dewey. 
the medium in which culture exists and through which it is transmitted" (LW 12:2728; see PP: 25). He quotes a similar passage a couple of pages later that repeats Dewey's claim to be using "language" "in its widest sense" as "culture" (PP, 27; LW 14:50). This is more than, as Brandom thinks, "instituting conceptual norms and applying them" (PP: 26). This is Dewey's version of Dasein: our human existence is inherently cultural co-existence, living as an inheritor, inhabitant and transmitter of living culture, to which Dewey also gives the name "mind" (LW 1:169 f.). In other words, education is a fundamental feature of human existence, a feature of our way of being-in-the-world. Here is where the "question of language" should begin ${ }^{47}$. We are inhabiting the world together; all of us will die, but culture will be passed along and the universe of meaning sustained. Education and learning are also involved with our basic human existence: it tells us something basic about what we are existentially, teachers and learners. Education is the cultural dialogue of death and life ${ }^{48}$.

Thus, insofar as the classical, experiential pragmatists are characterized (as Brandom portrays them) as giving too little attention to language, the opposite oddly turns out to be true. If "language" is taken to be the full symbolic mode of human existence, embracing culture, history, art, education and all the forms of nonverbal communication and care, it is "they", not "we", who have neglected the vast spectrum of human meaning to focus on rather narrow and in many cases highly artificial topics. Even as far as the study of language goes, shouldn't a linguistically oriented pragmatism have culturally diverse, anthropologically informed discussions of the topic, relying on such resources as Benjamin Lee Whorf's famous discussion of the Hopi concept of time or Edward T. Hall's analysis of the role of nonverbal forms of communication in different cultures ${ }^{49}$ How can linguistic pragmatism make sense of music, meditation, dance, painting, ceremony, shared silence? ? $^{50}$

\section{Toward a Cultural Pragmatism}

What would a cultural pragmatism (or ecological humanism) look like? I can briefly indicate some ways in which I have tried to work out such an approach just to provide a contrast with the overly narrow agenda of "linguistic pragmatism". It takes seriously Dewey's complex idea of experience and his expanded view of the range of cultural meanings beyond verbal usage and rule-governed language games; in other words, it accepts seriously what the linguistic pragmatist would reject. In dealing with the problem of meaning it would try to understand it not in terms of propositional

47. See Daniel N. Stern, The Interpersonal World of the Infant, (1985). See especially ("The Sense of the Verbal Self", Chapter 8).

48. Dewey makes this point at the very beginning of Democracy and Education (MW: 9).

49. See Benjamin Lee Whorf, "An American Indian Model of the Universe", in Language, Thought and Reality (1956), Edward T. Hall, The Silent Language (1973), and The Hidden Dimension (1969), and Clifford Geertz, The Interpretation of Cultures (1973), and Local Knowledge (1983).

50. See Junichiro Tanizaki's brilliant monograph, In Praise of Shadows, trans. Thomas J. Harper and Edward G. Seidensticker (1977), for a study of the cultural significance of indeterminacy, mystery, the recessive (yin), and the void (sunyata) in classical Japanese culture. 
units and modes of inference, but in terms of the human need (or eros) for meaning and the ways that need is met in existence.

It therefore begins with a thesis about human existence, which I call "the Human Eros": human beings have a basic need to experience existence with meaning and value; otherwise we suffer and $\mathrm{die}^{51}$. This is an existential or ontological claim about human nature and can only be defended by asking what happens when meaning and value are drained from an individual's life or the life of a group: What does it take to destroy a human life? - a different question that what it takes to kill someone - to rob the individual of any sense of meaning and value. Why do native peoples suffer as their cultures are engulfed by industrial "civilization"? This question of meaning is not about propositions and has everything to do with understanding life primarily from the relation of meaning to the welfare of human existence. Psychotherapist Viktor Frankl has left us a testimony of his first-hand experience as a prisoner in a Nazi concentration camp and what happens to people when all sense of value and meaning is stripped away ${ }^{52}$. As a result, Frankl came to this conclusion, "Man's search for meaning is the primary motivation in his life and not a 'secondary rationalization' of instinctual drives. This meaning is unique and specific in that it must and can be fulfilled by him alone; only then does it achieve a significance which will satisfy his own will to meaning" 53 .

A second thesis accompanying that of the Human Eros is that our various cultures can be described as "spiritual ecologies" 54 . Human beings inhabit nature through culture and culture is what provides the environment of meaning to sustain the Human Eros. We do not exist merely as biological - much less as neurological - beings; we exist through culture. Different cultures have found different ways to weave a spiritual ecology of meaning and value around those who live within it. But each culture can be understood as one possible answer to the questions "What is the meaning of life? How shall we live?" One aim of cultural pragmatism is to examine these ecologies of meaning and the consequences that flow from them, i.e., cultural praxeis ${ }^{55}$. By examining the worlds of human meaning and how they are embodied in cultural action there would be a larger sense of the possibilities of meaning through which we could critically reflect on our own culture. Possibilities would be operative as immanently present. Cultural pragmatism would take up the critical question of how the Human Eros might best be served - what sort of world would it be in which human existence found its greatest fulfillment? How should cultures seek to enrich the

51. This is discussed in my book The Human Eros (2013). See especially the "Introduction" and the essays "The Human Eros" and "Eros and Spirit".

52. See Viktor Frankl, Man's Search for Meaning (1984)

53. Frankl (1984: 105). Frankl leaves the matter at the level of individual response - he was a psychiatrist treating individuals after all - and does not take it to the level of general culture as I do.

54. The term "spiritual" may be disturbing to hardnosed naturalists, but I use it not only to designate the "Geistlich" aspect of culture but that what values and beliefs are at the core of a culture are embodiments of what that culture thinks of as sacred, be they "supernatural" by the standards of contemporary science or not.

55. One of the key points that William James makes in the first lecture in Pragmatism is that he is mainly interested in our beliefs not in terms of narrow "success" but as life-hypotheses - what is the meaning of my life as it is to be lived if I decide to believe this world hypothesis rather than that? 
possibilities for meaningful existence? Perhaps those cultures are richest that provide the best resources for people to live meaningful lives. Perhaps this concern should be a primary aim of education.

Cultural pragmatism would explore various ways in which cultures establish worlds of meaning. As a brief example here I will focus on the idea of Mythos. (The term "myth" has been hopelessly lost to the overriding sense of "false story".) By Mythos, I mean a core event, story, belief, or meaning that is central to the selfidentity of a person, group or cultural world. Mythoi are one of the primary ways in which we experience the meaning of ourselves, our cultures and the world ${ }^{56}$. Mythos is a pervasive phenomenon in human existence, fundamental to our human being. Mythos is a way of maintaining a sense the values and meanings sustaining our lives such that, if it were somehow removed, damaged, or destroyed it would either constitute a crisis of meaning for that person, group or culture. Thus a Mythos has to do with a sense of who one is, who we are (what it means to be a member of a group of culture) and what the world means. On a personal level, for example, we all have certain key stories that embody for us a sense of our self-identity, of who we are ones which if lost to memory would change us fundamentally. This can range from stores about where we grew up and when, generally innocuous but important for us, to those about crisis events in our lives or deep traumas. The same is true of groups. This, after all, is why the study of history and how it is taught becomes so charged with the way it is told. It is more than odd for Native Americans to be told of the "discovery of America" or "how the West was won". If one of these core stories is radically altered, eroded, or destroyed completely it has devastating impact upon the person or group that had constituted its identity, the sense of self and world, through it.

Cultures, like persons, often repeat Mythoi in various ways as restorations and renewals of the meaning of self, group and world. From fairly mild celebrations, like the Fourth of July, to solemn and charged religious rituals, like Easter or the Pueblo corn dances, such ceremonies are enacted to reaffirm those key ideas and values that make the members of a culture who they are. Thus, while Mythoi may be embodied in cultures or personal memories as stories, they may be also be embodied in nonverbal ways: dances, clothing, song, ritual and so on. These Mythoi, if lost, changed, or eroded, will change the meaning of what it is to be a member of that culture just as an episode of Alzheimer's will erode the self of the meaning of one's life. Sometimes it may mean that a better meaning has replaced or transformed a worse. Progressive Muslims wish to have the meaning of the word jihad, "struggle", to mean primarily the struggle to achieve justice and peace in the world and in oneself. American culture has core values in the idea of individualism and freedom and numerous Mythoi cluster about each of

56. A more technical definition is: "Mythos is a symbolic structure that provides a key element in creating and preserving a sense of self and world, the meanings that define existence. Cultures have Mythoi, but so do groups within a culture and particular individuals. A Mythos is not a 'myth' (a false story) but an important story or symbolic structure. It conveys a fundamental sense of existential truth, truth in the sense in which a personal story about one's past is regarded as 'existentially true' and not just as factually true. Tribal myths and rituals are archaic forms of mythoi - there is something of the sacred in their presence. The structure may be narrative but need not be. The structure of a temple may also be a Mythos. Philosophical systems are Mythoi" (Alexander 2013: 421). 
these tropes. The close interweaving of these tropes has led to the impasse on dealing rationally with gun laws. The point is that meeting the human need for inhabiting a world of meaning is one of the aims of culture, and culture involves recurrent embodiments of core meanings and values, especially as embodied in Mythoi, as renewed affirmations of the meaning of self, group and world. Thus part of a cultural pragmatism would be a study of various key Mythoi in cultures and how those Mythoi are embodied and perpetuated, modified or effaced. Perhaps the study of our Mythoi might make us more critically aware of the tensions and conflicts at the core of our culture.

One final example of a theme in cultural pragmatism is that of tropes. By "trope" I mean a core idea or value that constitutes the world of a culture ${ }^{57}$. In classical Greek culture the idea of virtue or excellence, arete , was a trope that was thematized in a wide variety of ways, from the poems of Homer to images on temples to the Olympic games to the dialogues of Plato. Thus a trope may find embodiment in media other than stories (such as gymnasia or athletic games) but be symbolically communicative nonetheless. Indeed a statue of an athlete may tell more in an instant about Greek culture than anything else. A trope of American culture is freedom. We embody this trope in countless ways, from movies to advertising to foreign policy.

Cultures have a plurality of core tropes that can exist in supportive or tensive relation to each other. For example, the American trope of freedom is related to that of individuality. In some ways these support each other, but there are types of individual behavior that can come into conflict with the ideal of freedom. One of the functions of cultural creation is to try to clarify and resolve these conflicts and tensions. Greek culture extolled the ideal of excellence and that striving for it is good; but against this it set the sin of hubris or excess which destroys arete. Thus many Greek stories involve the "tragic hero" who achieves greatness and then is destroyed through not knowing his proper limit. This is the undercurrent of that core text of Greek culture, The Iliad: Achilles has been greatly insulted, but his anger is excessive and the result is that his best friend is killed, which drives him to further excess. In his excess, Achilles' heroic status is threatened. That is moderation, self-control, knowing oneself are essential to the pursuit of excellence. The story ends when at last he can recall himself to the limits of human mortality and surrender the body of Hector to Priam. Similar tensions between tropes are found in literature, religion and philosophy around the world. The Book of Job deals with a profound tension between core tropes of Judaism, the goodness of God and His power. The Bhagavad Gita seeks to reconcile the performance of duty (dharma) with devotional yoga. The Summa Theologiae seeks to harmonize faith and reason.

Such at least is one way that a philosophy based on Dewey's cultural naturalism "cultural pragmatism" if we must - can develop in a new direction without succumbing to the narrowness of Anglophone philosophy or to the conversational relativism that Rorty exhibited. It can aim at being intelligent, culturally literate, and willing to talk

57. Specifically, a trope is "An archetypal core meaning or value that a culture uses to understand itself and which, therefore, needs exemplification. A trope avails itself of any number of types or various intermediary forms that become recurrent cultural themes at a certain generic level; e.g., the Cowboy, the Rebel, the Patriot, etc. may all be types relating to the trope of Freedom" (Alexander 2013: 420). 
beyond its own jargon if it is to do any good. It comes down to a conception of human existence, as I said at the beginning. I think the vision of our human being as epistemic knowing machines or rational moral agents is the anemic result of an empiricism without much experience.

\section{References}

Alexander T. M., (1987), John Dewey's Theory of Art, Experience and Nature: The Horizons of Feeling, Albany, NY: The State University of New York Press.

- (2013), The Human Eros: Eco-Ontology and the Aesthetics of Existence, New York, NY: Fordham University Press.

Brandom R., (2011), Perspectives on Pragmatism, Cambridge, MA: Harvard University Press.

Dewey J., (1977a), "Beliefs and Existences”, in The Middle Works, volume 10, ed. by Jo Ann Boydston, Carbondale, IL: Southern Illinois University Press, 83-100.

- (1977b), “The Intellectualist Criterion of Truth", in The Middle Works, volume 4, ed. by Jo Ann Boydston, Carbondale, IL: Southern Illinois University Press, 5075 .

- (1978a), "Brief Studies in Realism", in The Middle Works, volume 6, ed. by Jo Ann Boydston, Carbondale, IL: Southern Illinois University Press, 103-122.

- (1978b), Studies in Logical Theory, in The Middle Works, volume 2, ed. by Jo Ann Boydston, Carbondale, IL: Southern Illinois University Press, 293-378.

- (1980), "The Need for a Recovery of Philosophy", in The Middle Works, volume 10, ed. by Jo Ann Boydston, Carbondale, IL: Southern Illinois University Press, 3-48.

- (1981), Experience and Nature, in The Later Works, volume 1., ed. by Jo Ann Boydston, Carbondale, IL: Southern Illinois University Press.

- (1983a), A Syllabus: Types of Philosophic Thought, in The Middle Works, volume 13, ed. by Jo Ann Boydston, Carbondale, IL: Southern Illinois University Press, 349-96.

- (1983b), Human Nature and Conduct, in The Middle Works, volume 14, ed. by Jo Ann Boydston, Carbondale, IL: Southern Illinois University Press. 
Dewey J., (1984a), "Philosophy and Civilization”, The Later Works, volume 3, ed. by Jo Ann Boydston, Carbondale, IL: Southern Illinois University Press, 3-10.

- (1984b), "Qualitative Thought" in The Later Works, volume 5, ed. by Jo Ann Boydston, Carbondale, IL: Southern Illinois University Press, 243-262.

- (1984c), The Quest for Certainty, in The Later Works, volume 4, ed. by Jo Ann Boydston, Carbondale, IL: Southern Illinois University Press.

- (1986), Logic: The Theory of Inquiry, in The Later Works, volume 12, ed. by Jo Ann Boydston, Carbondale, IL: Southern Illinois University Press.

- (1987), Art as Experience, in The Later Works, volume 10, ed. by Jo Ann Boydston, Carbondale, IL: Southern Illinois University Press.

- (2012), Modern Philosophy and Unmodern Philosophy, ed. by Philip Deen, Carbondale, IL: Southern Illinois University Press.

Flower E. and Murphy M., (1977), A History of American Philosophy, New York, New York: G.P. Putnam's Sons.

Frankl V., (1984), Man's Search for Meaning, New York, NY: Simon and Schuster.

Geertz C., (1973), The Interpretation of Cultures, New York, NY: Basic Books.

Goodman R., (1990), American Philosophy and the Romantic Tradition, Cambridge: Cambridge University Press.

Hall E. T., (1969), The Hidden Dimension, New York, NY: Anchor Books.

— (1973), The Silent Language, New York, NY: Anchor Books.

James W., (1890), The Principles of Psychology, 2 volumes, New York, NY: Henry Holt.

- (1967), The Writings of William James, ed. by John McDermott, Chicago, Ill.: Random House.

Lamont C., (1961), "New Light on Dewey's Common Faith", The Journal of Philosophy, 58, 1, 21-28.

Marcuse H., (1964), One Dimensional Man, Boston, MA: Beacon Hill. 
Mead G. H., (1950), Mind, Self, and Society, ed. by Charles Morris, Chicago, IL: Chicago University Press.

Mill J. S., (1961), “Bentham”, in The Philosophy of John Stuart Mill, ed. by Marshall Cohen. New York, NY: The Modern Library.

Price H., (2013), Expressionism, Pragmatism, and Representationalism, Cambridge: Cambridge University Press.

Rorty R., (1979), Philosophy and the Mirror of Nature, Princeton: Princeton University Press.

- (1982), Consequences of Pragmatism: Essays 1972-1980, Minneapolis: University of Minnesota Press.

Russell B., (1964), Wisdom of the West, New York: Random House.

Schilpp P. A., ed., (1951), The Philosophy of John Dewey, New York, NY: Tudor Publishing, $2^{\text {nd }}$ ed.

Stern D. L., (1986), The Interpersonal World of the Infant, New York, NY: Basic Books.

Tanizaki J., (1977), In Praise of Shadows, translated by Thomas J. Harper and Edward Seidensticker, Sedgwick, ME: Leete's Island Books Inc.

Thayer H. S., (1981), Meaning and Action: A Critical History of Pragmatism [1968], Indianapolis, IN: Bobbs-Merrill Inc.; Hackett Publishing, Indianapolis, $2^{\text {nd }}$ ed.

Whorf B.L., (1956), "An American Indian Model of the Universe”, in Language, Thought and Reality, Boston, MA: The MIT Press.

Wilshire B., (2002), Fashionable Nihilism: A Critique of Analytic Philosophy, Albany, NY: State University of New York Press, 2002. 